\title{
The Imagery In Perihal Gendis Poetry Book By Sapardi Djoko Damono And Its Application As Drilling Material For Literature Learning In High School
}

\author{
Krisna Wijayakusuma ${ }^{1}$, Teguh Supriyanto ${ }^{2}$, Mukh Doyin ${ }^{3}$ \\ \{krisnawijaya702@gmail.com ${ }^{1}$, teguh.supriyanto@mail.unnes.ac.id ${ }^{2}$, mukhdoyin@mail.unnes.ac.id $\left.{ }^{3}\right\}$ \\ Postgradute Program of Universitas Negeri Semarang, Indonesia ${ }^{1,2,3}$
}

\begin{abstract}
The researcher examined the imagery in Perihal Gendis book poetry that was classified as the most recent poems written by Sapardi. This study aimed at (1) analyzing the imagery used by Sapardi in Perihal Gendis poetry book. (2) describing the application of the findings as drilling material for literature learning in Grade X of High School. This is a qualitative research with a stylistic approach. The research data were acquired from Perihal Gendis poetry book by Sapardi. The data were collected through heuristic reading and literature. According to the data analysis, there were several finding gained: (1) there were 143 imagery data found in the research. The most frequent imageries are kinesthetic imagery with 48 data found, auditory imagery with 41 data, and visual imagery with 38 data; and 2) The imagery aspects collected from Perihal Gendis poetry Book by Sapardi was applied as the drilling material for students in Grade X of High School and was administered in two steps of activities, those are exploratory skill activities and process skill activities.
\end{abstract}

Keywords: imagery, drilling material for literature learning

\section{Introduction}

Literary works are the representation of language phenomena that has a significant standing among the studies of literature (Supriyanto, 2011). On the other hand, Munir (23) argues that literary works are the form of word play or writer's language that intends to convey certain message which will be delivered by the literary connoisseur. Yet, literary works may also be classified as fiction story depends on the genre of the work piece.

According to literature, genre is divided into two categories, those are imaginative and nonimaginative (Umami, 2009). The style of delivery, through figurative style and imagery, determines the objective of the poet in conveying the expression as well as setting the difference in characteristic in comparison to other work piece (Yono dan Mimi, 2017). Imagery is directly related to the essence of literary works that is always full of intensity. Nurgiyantoro (2014) states that imagery consists of auditory, kinesthetic, olfactory, visual, tactile, gustatory, and intellectual imagery.

This study choose the poem of Perihal Gendis by Sapardi Djoko Darmono as the subject of the study. This is because the poems by Djoko Damono generally have special characteristic 
in terms of stylistic. This characteristic is found on the strong usage of image in every poem. It shows that Sapardi has strong sense of imagination in generating a literary work.

According to Widianto and Zulaiha (2016) language and culture in literature has always been closely blend and support each other as a learning program. Therefore, poem stylistic study on the imagery aspect, specifically, would be more beneficial if applied to the learning of literature at school. Based on the arguments presented above, this stylistic study on imagery aspect is considered essential to be conducted.

This research aims at: a. Describing the imagery inside The poetry books of Perihal Gendis by Sapardi Djoko Damono. b. Describing the application of imagery aspect from the Perihal Gendis Poetry Book by Sapardi Djoko Damono as the learning material of literature in High School.

This research is relevant to the previous studies conducted by several researchers about stylistic, particularly on the diction, imagery, words, concrete, and figurative language (Rosid, 2011), (Effendi, 2013), (Mukhlis, 2018), (Khan, 2015) dan (Anindita, 2017). However, the focus of this research is analyzing the imagery used in Prihal Gendis poetry book.

\section{Method}

The approach used in this research is stylistic approach. Based on the explanation presented above, aside of analyzing poems based on the imagery aspect, this study also intends to convey the implicit meaning from the poems by Sapardi in his poetry book entitled Perihal Gendis that has never been analyzed before. Qualitative research design is applied in this study. The natural object in this study is the data quotation which are the imagery acquired from Perihal Gendis poem anthology. In this study, the researcher acts the key instrument. Therefore, this research relies on the accuracy, sensitivity, and depth of the researcher in collecting the data and presenting the result of the analysis regarding the representation of the meaning from Perihal Gendis poetry book. The data collected in this research are language units such as word, phrase, clause, and sentence. Those are the imagery data collected from the poetry book Perihal Gendis by Sapardi Djoko Damono and published by Gramedia Pustaka Utama in October 2018.

\section{Results and Discussions}

\subsection{The Imagery in Perihal Gendis Poetry Book by Sapardi Djoko Damono}

The results and discussion for the imagery aspect from Perihal Gendis poetry book by Sapardi Djoko Damono consist of the imagery used in the poem, The most dominant imageries found in this poem are visual imagery, auditory imagery, and kinesthetic imagery.

Kinesthetic Imagery. This imagery is the most frequent imagery found in the poetry anthology of Perihal Gendis. Kinesthetic imagery meant to depict something that is immobile as if it is able to move or simply portraying a movement in general. Below is the quotation from the data analysis which is categorized as kinesthetic imagery.

Baru kali ini langit tampak serupa benar dengan mata, Meneteskan butir-butir air ke udara yang penat yang gerah Yang sumpek. 
Kinesthetic imagery as shown in the data of (1) poem line. The poem abve is title Pada Suatu Hari Sekitar Jam 4 Sore. The imagery is indicated by the words Meneteskan butir-butir ke udara. The words use kinesthetic imagery that portray natural phenomenon, specifically, the process of dew formulated or rain falling to a hot dry ground.

Auditory Imagery. Other imagery that is also repeatedly appeared in Perihal Gendis poetry book is auditory imagery. Auditory imagery is used to stimulate various memories of events and life experiences in respect to hearing.

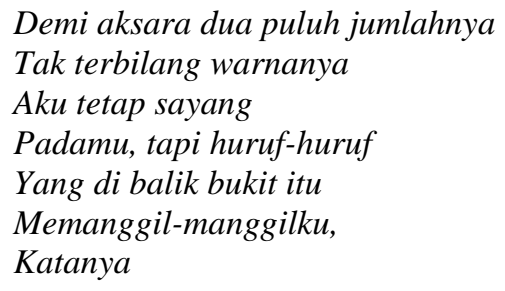

(Citraan Pendengaran/SDD/22/2018)

Auditory imagery appears in the poem title percakapan di luar riuh suara. It can be seen in the data quotation (2) from the words memanggil-manggilku, the words indicate an activity to utterly listen using the sense of hearing. The auditory imagery in the data encourage the reader to as if hearing the voices or be carried away by the events in the poem. In other words, there are two functions of auditory imagery. First, it stimulates the imagination of the reader. Second, it helps building the atmosphere of the poem.

Visual Imagery. Other than kinesthetic and auditory imagery, visual imagery is also repeatedly found and most often used in Perihal Gendis poetry book. Visual imagery is commonly used to describe the physical or the characteristic of a character, situation, and the setting of place. Below is the example of visual imagery data.

Bangkit dari tempat tidur

Lari ke jalan memandang

As seen in data (3) above is the visual imagery. The data of poem lines above is the part of a poem titled Apa Sebaiknya Aku Tidak Bermimpi Lagi. The visual imagery above intends to generate the situation of the poem. The situation portrayed in the poem is hastiness or curiosity. It is emphasized by the lines before the visual imagery appeared, that is the line that says Bangkit dari tempat tidur. Not only to generate the situation, the imagery in the poem line also meant to depict the setting and the situation around.

\subsection{The Application of Imagery as the Drilling Material for Literature Learning in High School}

The stylistic aspect in the poetry anthology of Perihal Gendis may serve as the drilling material for learning literature in High School through exploratory activities and process skill activities. The followings are the example of the drilling aspects.

Exploratory Activities. In terms of exploratory, the instruction that require students to learn about imagery aspect is based on the formulation of KI 3/KD 3.16 and KD 3.17. It can be seen 
from the drilling activity through multiple choices and short answer exercises given to the students.

Drilling Through Multiple Choices. Multiple choices exercises about imagery aspect is given during the learning in order to provide variation, different types, and different form of exercises though the objective is still similar. Below is the example of multiple choice exercises to measure the students' comprehension on the type of imagery aspect.

Imagery that stimulates and arouses the reader's imagination through the association of bitter, sweet and sour taste is categorized as ...

a) Kinesthetic imagery

b) Intellectual imagery

c) Gustatory imagery

d) Tactile imagery

e) Auditory imagery

Exercise (1) above shows the activity in assessing the students' comprehension on the types of imagery.

Drilling Material Through Short Answer Exercises. Test activity through short answer exercises is used to measure the students' cognitive skill.

In literary works, imagery that plays an important role to create imaginative portrayal, build a mental image and create certain experience to the readers called ....

Exercise (2) above requires the students to mention the type of the imagery. The exercise used operational verbs listed in the cognitive class, that is 'mention'. Short answer exercises have the same objective as multiple choices exercises. But, by providing different types of exercises will give variation and alternatives for the same objective.

\subsection{Process Skill Activities}

In the learning of literature for High School students, they learn about stylistic aspect, especially related to the imagery aspect. The activity of process skill that relevant to the poem text learning is KI 4/ KD 4.17. The learning process at school, such as drilling activity, is implemented to improve the process skill. The exercise (3) is the example of drilling activity used measure students' skill in analyzing and identify the elements of a poem. Additionally, process skill aims at improving the ability to create a work piece, that is writing a poem without neglecting the elements in it. It can be seen in the exercise (4) below.

Tak ada lagi bulan purnama

Dilangit berserakan Kristal

Tak henti-hentinya berjatuhan

Di pekarangan belakang rumah

Di sela-sela cerlang gerimis

Didengarnya suara

Tertangkap

Dan lepas lagi

Tertangkap lagi 
Dan lepas.

(Duduk di Teras Belakang Waktu Bulan Purnama /iii/, Damono, 2018)

Analyze the poem above based on the following aspects;

a) Imagery,

b) Situation, and

c) Meaning of the poem.

Formulate a freestyle poem \& make sure to include all the elements of the poem!

Exercise (4) is the example of exercise type that allow the students to improve their skill process in creating a poem based on their imagination. From the exercise examples shown above, there are two benefits in using them, those are improving the students' exploratory skill and improving the students' ability to write a poem.

\section{Conclusion}

There are two conclusions in this research, those are 1) Imagery that is mostly used in Perihal Gendis poetry book is kinesthetic imagery, visual imagery, and auditory imagery; 2) Imagery aspect is relevant to and may be used in the drilling activity for High School students since it is in accordance to KI 3/KD 3.16 and KD 3.17 as well as KI 4/KD 4.16 and 4.17. The drilling activity is conducted in two steps of activity. The first step is exploratory activity and the second is process skill activity. 


\section{References}

[1] Anindita, K. A., Satoto, S. \& Sumarlam.: Diction in Poetry Anthology Surat Kopi by Joko Pinurbo as A Poetry Writing Teaching Material. Vol. 2, pp. 39-4. International Journal of Active Learning (2017).

[2] Effendi,: Kemampuan Menentukan Citraan Puisi Karya Sapardi Djoko Damono pada Siswa SMP. Vol. 1, pp. 23-34. Jurnal Kata: Bahasa, Sastra, dan Pembelajarannya (2013).

[3] Khan, et all.: Stylistic Analysis of the Short Story 'The Last Word' by Dr. A. R. Tabassum. Vol. 6, pp. 11-23. Jurnal Advances in Language and Literary Studies (2015).

[4] Mukhlis, et all.: Aspek Stilistika dalam Antologi Puisi Melipat Jarak Karya Sapardi Djoko Damono dan Pemanfaatannya Sebagai Materi Pengayaan Sastra. Vol. 3, pp. 10-17. Jurnal Pendidikan Bahasa dan Sastra Indonesia (2018).

[5] Munir, Saiful.: Diksi dan Majas dalam Kumpulan Puisi Nyanyian Dalam Kelam Karya Sutikno W.S : Kajian Stilistika.Vol. 2, pp. 1-10. Seloka (2013).

[6] Nurgiyantoro, Burhan.: Stilistika. Gadjah Mada University Press, Yogyakarta (2014).

[7] Rosid, Abdul.: Kajian Stilistika dan Nilai Budaya dalam Puisi Indonesia Sebagai Bahan Pembelajaran Sastra Bagi Siswa Kelas VIII MTs Misykat Al-Anwar Krawon Diwek Jombang. Sekolah Pascasarjana Universitas Pendidikan Indonesia, Bandung (2011).

[8] Supriyanto, Teguh.: Kajian Stilistika dalam Prosa. Elmatera, Yogyakarta (2011).

[9] Umami, Imam Mahdil.: Analisis Wacana Penggunaan Gaya Bahasa dalam Lirik Lagu-lagu Ungu: Kajian Stilistika. Vol. 3, pp. 201-217. Dinamika Bahasa \& Budaya (2009).

[10] Widianto, Eko, dan Ida Zuleha.: Pilihan Bahasa dalam Interaksi Pembelajaran Bahasa Indonesia Bagi Penutur Asing. Vol. 5, pp. 124-135. Seloka: Jurnal Pendidikan Bahasa dan Sastra Indonesia. (2016).

[11] Yono, Robert Rizki, dan Mimi Mulyani.: Majas dan Citraan dalam Novel Kerling Si Janda Karya Taufiqurrahman Al-Azizy. Vol. 6, pp. 200-207. Seloka: Jurnal Pendidikan Bahasa dan Sastra Indonesia. (2017). 